\title{
Jaw Bite Force to Predict Masseter Muscle Thickness and Swallowing Functions
}

\author{
Masseter Kas Kalınlığı ve Yutma Fonksiyonlarını Tahmin Etmede Çene Isırma Kuvvetinin Yeri
}

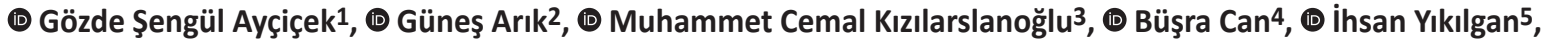 \\ (D) Mahmut Duymuş6, (D) Zekeriya Ülger ${ }^{1}$ \\ ${ }^{1}$ Kırıkkale University Faculty of Medicine, Department of Internal Medicine, Division of Geriatrics, Kırıkkale, Turkey \\ 2 University of Health Sciences Turkey, Ankara City Hospital, Clinic of Internal Medicine, Division of Geriatrics, Ankara, Turkey \\ 3 University of Health Sciences Turkey, Konya Training and Research Hospital, Clinic of Internal Medicine, Division of Geriatrics, Konya, Turkey \\ ${ }^{4}$ Marmara University Faculty of Medicine, Department of Internal Medicine, Division of Geriatrics, Istanbul, Turkey \\ ${ }^{5}$ Gazi University Faculty of Dentistry, Department of Restorative Dentistry, Ankara, Turkey \\ 6Special TESLA EMAR Imaging Center, Ankara, Turkey
}

\section{Abstract}

Objectives: The age-related changes in the masticatory muscles and teeth lead to large spectrum of problems from malnutrition to death in the elderly. The aim of this study is to investigate the relationship among bite strength, chewing muscle thickness, and swallowing difficulty.

Materials and Methods: A total of 58 patients (47 over 65 years old and 11 young) were included in the study. After a comprehensive geriatric assessment of the older adults, the jaw bite force was assessed with pressure sensitive sensor and chewing muscles thicknesses were measured with ultrasound in both groups. The swallowing difficulty was determined by the eating assessment tool (EAT-10).

Results: The median age was 71 years (minimum-maximum: $21-85$ ) and $48.3 \%$ of the participants were women. Bilateral jaw bite force scores and masseter muscles thicknesses were lower in the elderly than in the young patients and in the patients with tooth prosthesis than in those without prosthesis $(p<0.05, p<0.01$, respectively). There was a positive correlation between jaw bite force and masseter muscle thicknesses $(p<0.05)$. Jaw bite force was positively correlated with handgrip strength (right $r=0.428, p=0.002$ and left $r=0.347, p=0.007$ ). Both right and left jaw bite forces were negatively correlated with EAT-10 scores ( $r=-0.342, p=0.017$ and $r=-0.383, p=0.005$, respectively).

Conclusion: Decreasing of the jaw bite force and masseter muscle thickness with age may be the reporter of malnutrition and swallowing difficulty. Further studies are needed with larger number of patients to determine if these parameters predict jaw bite force and swallowing dysfunction in older adults.

Key Words: Jaw Bite Force, Masseter Muscle, Muscle Strength, Older Adults

\section{Öz}

Amaç: Çiğneme kaslarında ve dişlerde yaşa bağlı değişiklikler, yaşlılarda yetersiz beslenmeden ölüme kadar geniş bir yelpazede sorunlara yol açar. Bu çalışmanın amacı çene ısırma kuvveti, çiğneme kas kalınlığı ve yutma güçlüğü arasındaki ilişkiyi incelemektir.

Gereç ve Yöntem: Çalışmaya toplam 58 hasta (65 yaş üstü 47 ve 11 genç) dahil edildi. Yaşlı erişkinlerin kapsamlı geriatrik değerlendirmesinin ardından her iki grupta da çene ısırma kuvveti basınca duyarlı sensör ile değerlendirildi ve çiğneme kasları kalınlıkları ultrason ile ölçüldü. Yutma güçlüğü yeme değerlendirme aracı (EAT-10) ile belirlendi.

Bulgular: Ortanca yaş 71 yıl idi (minimum-maksimum: 21-85) ve katılımcıların \%48,3'ü kadındı. Bilateral çene ısırma kuvveti skorları ve masseter kas kalınlıkları yaşlı hastalarda genç hastalara göre, diş protezi olanlarda ise protezi olmayanlara göre daha düşüktü $($ sırasıyla $p<0,05, p<0,01)$. Çene ısırma kuvveti ile masseter kas kalınlıkları arasında pozitif korelasyon vardı $(p<0,05)$. Çene ısırma kuvveti el sıkma kuvvetiyle pozitif yönlü korelasyon

Address for Correspondence/Yazışma Adresi: Gözde Şengül Ayçiçek,

Kırıkkale University Faculty of Medicine, Department of Internal Medicine, Division of Geriatrics, Kırıkkale, Turkey

Phone: +90 5335716851 E-mail: gzdsengul@gmail.com ORCID ID: orcid.org/0000-0003-0528-8851

Received/Geliş Tarihi: 29.09.2020 Accepted/Kabul Tarihi: 16.02.2021

๑Copyright 2021 Ankara University Faculty of Medicine

Journal of Ankara University Faculty of Medicine is published by Galenos Publishing House.

All content are under CC BY-NC-ND license. 
gösterdi (sağ $r=0,428, p=0,002$ ve sol $r=0,347, p=0,007$ ). Hem sağ hem de sol çene ısırma kuvveti EAT-10 skorları ile negatif yönlü korelasyon gösterdi (sırasıyla $r=-0,342, p=0,017$ ve $r=-0,383, p=0,005$ ).

Sonuç: Yaşla birlikte çene ısırma kuvvetinin ve masseter kas kalınlığının azalması, yetersiz beslenme ve yutma güçlüğü habercisi olabilir. Bu parametrelerin yaşı ı erişkinlerde çene ısırma kuvvetini ve yutma fonksiyon bozukluğunu öngörüp öngörmediğini belirlemek için daha fazla sayıda hasta ile daha fazla çalışmaya intiyaç vardır.

Anahtar Kelimeler: Çene Isırma Kuvveti, Masseter Kası, Kas Kuvveti, Yaşlııı

\section{Introduction}

Skeletal muscle mass and muscle strength are expected to reduce with aging. In older adults, masticatory muscles are also influenced from this process. The masseter muscle, one of these muscles, becomes thinner with aging and chewing and swallowing difficulties occur (1). The reduction in masseter muscle thickness, has also been shown to be related to a reduction in occlusal force and chewing ability, leading to difficulties in eating, and risk of malnutrition (2). Additionally several studies have shown that this process is effected from tooth loss $(3,4)$. Dental health is closely associated with nutritional status and suggest that status of dentition should be considered in nutritional counseling and assessment of older adults (5).

Recently, European working group on sarcopenia in older people (EWGSOP) has pointed out that clinical value of sarcopenia definition only due to muscle mass is limited and muscle strength seems to be more relevant to the functionality than muscle mass. In the new sarcopenia criteria of 2018, EWGSOP2 used low muscle strength as the main parameter of sarcopenia. Probable sarcopenia is defined when only muscle strength declines. Combining low muscle strength with low muscle quantity or quality defines the sarcopenia. When low muscle strength, low muscle quantity/ quality and low physical performance are all detected, sarcopenia is considered as severe (6).

In previous studies effects of aging and sarcopenia on muscle strength and swallowing were evaluated. The authors mentioned, tongue pressure and jaw-opening force are useful to predict the decline of swallowing function, that may be important in preventing dysphagia (7) and pointed out that grip strength serve a role as a simple indicator for swallowingrelated muscle strength (8).

In the literature, investigations were focused on tongue pressure and jaw opening force, but the knowledge about jaw bite force as a predictor of muscle strength is lacking. Since, muscle strength seems to be more relevant to the functionality than muscle mass, in this study we aimmed to find out the relationship between bite strength, chewing muscle thickness, and swallowing difficulty.

\section{Materials and Methods}

\section{Patients}

A total of 47 patients admitted to the University Hospital geriatric outpatient clinic were included in the study. At the time of data collection, there were no widely acceptable standard validated values for jaw bite scores, for this reason we analyzed 11 healthy young as control group. The control group had no chronic diseases or any tooth problem (prosthesis etc.).

Patients with temporomandibular muscle disease, presence of myalgia in the face and chewing muscles, diagnosis of trigeminal neuralgia, diagnosis of Sjögren's syndrome, presence of chewing and swallowing problems due to moderate-toadvanced dementia or cerebrovascular event were excluded from the study.

\section{Comprehensive Geriatric Assessment}

All patients underwent comprehensive geriatric assessment (CGA) including Mini Nutritional Assessment-Short Form (9), Katz activities of daily living $(10,11)$, Lawton and Brody (12) instrumental activities of daily living, mini mental state examination (13), Yesavage depression scale (14) and clock drawing tests. CGA was performed by the geriatrician.

Grip strength dynamometer (Grip-D, Takei ${ }^{\circledR}$ ) was used to measure muscle strength from dominant hand. After 10 second intervals measurements were repeated for three times and maximum hand grip strength (HGS) value was recorded. For males $27 \mathrm{~kg}$ and for females $16 \mathrm{~kg}$ were used as the cut-off thresholds (6).

\section{Ultrasonographic Evaluation}

Ultrasonographic (US) estimates were obtained by a single trained sonographer with 11 years of experience in sonography.

Ultrasound device: Philips Affiniti 70G (Copyright Koninklijke Philips N.V. 2014, Andover, MA, 01810 USA) ultrasound device equipped with $12-5 \mathrm{MHz}$ linear transducer and 5-1 $\mathrm{MHz}$ convex transducer was used for B mode ultrasound.

Anatomical regions measured: We measured the thickness of bilateral masseter muscles (Figure 1). 
US examination: All the measurements were performed in supine position. The neck of the patient were in extention and all the muscles were in relaxed position. To avoid compression of the muscle a generous amount of ultrasound contact gel was applied to the probe. Muscles were measured at the level where thickness was greatest. All the measurements were done with linear transducer. The participants sat upright with no head support. The anterior border and subsequently the origin as well as insertion of the masseter muscle were palpated to locate the thickest part of the muscle as site for the measurement.

Jaw bite force measurement: Jaw bite force was measured from bilateral first molar site with pressure sensitive device (mod dental) in Newton (Figure 2).

\section{Statistical Analysis}

Statistical analysis was performed by using Statistical Package for Social Sciences for windows 20.0 software.

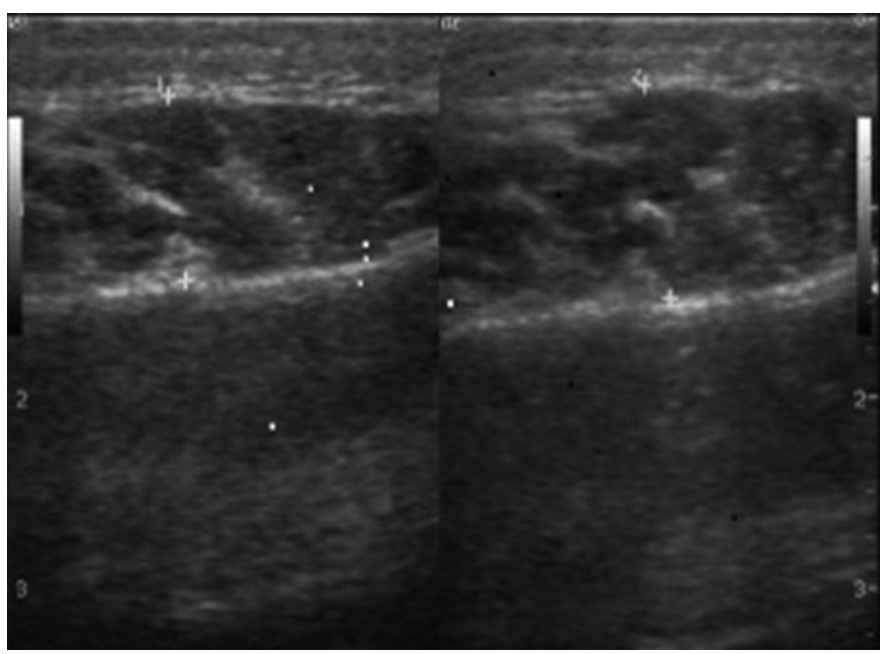

Figure 1: US evaluation masseter muscle contracted (left), relaxed (right). US: Ultrasonographic

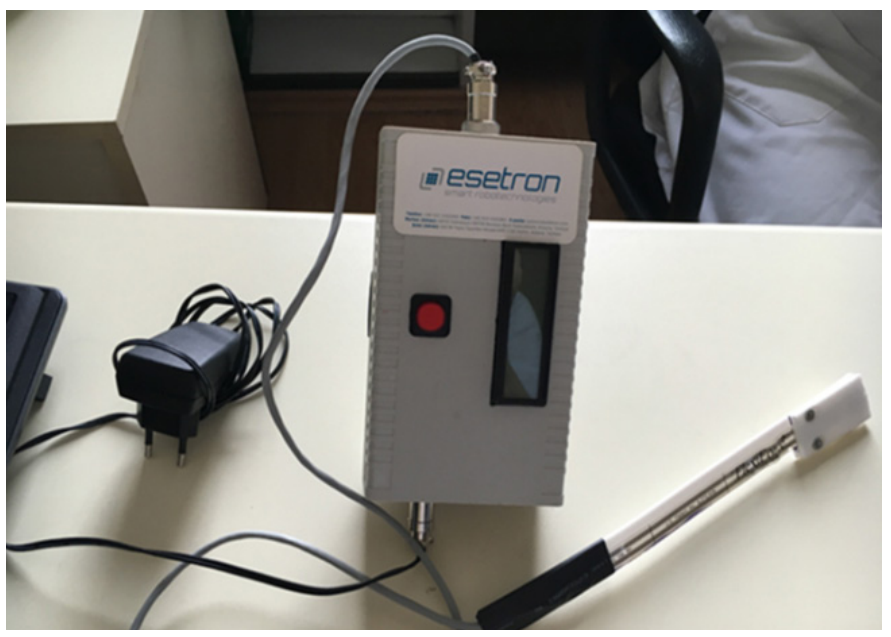

Figure 2: Jaw bite force measurement device
Numerical parameters were assessed by histogram and Kolmogorov-Smirnov test to evaluate whether the variables had normally distribution or not. Categorical variables were presented as frequencies and percentage. Comparison of continuous numerical parameters between two groups was done by using Student's t-test or Mann-Whitney $U$ test according to the distribution of the parameters as normal or skew distribution, respectively. Categorical parameters were compared with chi-square test. Correlation analysis were conducted with Pearson for normally distributed variables and with Spearman for not normally distributed variables. $\mathrm{P}<0.05$ was considered as statistically significant.

\section{Ethical Statement}

Ethical approval was obtained from the Local Ethical Committee (01/2016-110). This research was completed in accordance with the guidelines of the Helsinki Declaration. Written informed consent was obtained from all participants.

\section{Results}

The median age was 71 years [minimum (min)-maximum (max): 21-85] and 48.3\% of the participants were women. The median body mass index (BMI) was $27.3 \mathrm{~kg} / \mathrm{m}^{2}$ (min-max: 18.35-38.5). The incidence of hypertension, diabetes mellitus and coronary artery disease was 55.3\%, 29.8\% and $36.2 \%$, respectively (Table 1 ).

Bilateral jaw bite force scores and masseter muscles thicknesses were lower in the older adults than young patients and in the patients with tooth prosthesis than without prosthesis ( $p<0.01, p<0.05$, respectively) (Table 2 ).

There was a positive correlation between jaw bite force and masseter muscle thicknesses $(p<0.05)$. Jaw bite force was

Table 1: Demographic characteristics of the participants

\begin{tabular}{|c|c|c|}
\hline & $\begin{array}{l}\text { Older patients } \\
n=47\end{array}$ & $\begin{array}{l}\text { Younger patients } \\
n=11\end{array}$ \\
\hline Age & $74(65-85)$ & $29(21-42)$ \\
\hline Sex (\%, female) & 53.2 & 27.3 \\
\hline $\mathrm{BMI}\left(\mathrm{kg} / \mathrm{m}^{2}\right)$ & $27.7(21.6-35.3)$ & $24.9(18.3-38)$ \\
\hline $\mathrm{HT}(\mathrm{n}, \%)$ & \multicolumn{2}{|l|}{$26(55.3)$} \\
\hline DM $(n, \%)$ & \multicolumn{2}{|l|}{$14(29.8)$} \\
\hline CAD $(n, \%)$ & \multicolumn{2}{|l|}{$17(36.2)$} \\
\hline MNA-SF & \multicolumn{2}{|l|}{$11.6 \pm 3.2$} \\
\hline HGS & \multicolumn{2}{|l|}{$24.6 \pm 9.7$} \\
\hline EAT-10 & \multicolumn{2}{|l|}{$0(0-14)$} \\
\hline $4 \mathrm{~m}$ walking speed (m/sn) & \multicolumn{2}{|l|}{$1.7 \pm 0.9$} \\
\hline \multicolumn{3}{|c|}{$\begin{array}{l}\text { Results were shown as median (min-max) for non-parametric, as mean } \pm \text { SD for } \\
\text { parametric variables. } \\
\text { BMI: Body mass index, HT: Hypertension, DM: Diabetes mellitus, CAD: Coronary artery } \\
\text { disease, MNA-SF: Mini nutritionel assessment-short form, HGS: Handgrip strength } \\
\text { EAT-10: Eating assessment tool, min-max: Minimum-maximum, SD: Standard deviation }\end{array}$} \\
\hline
\end{tabular}


positively correlated with HGS (right $r=0.428, p=0.002$ and left $r=0.347, p=0.007)$. Both right and left jaw bite force were negatively correlated with the eating assessment tool (EAT-10) scores $(r=-0.342, p=0.017$ and $r=-0.383, p=0.005$, respectively) (Table 3).

Bilateral masseter muscle thicknesses were more thinner in females than men (right $7.9 \mathrm{~mm}$ (3.3-10.7) vs $10.4 \mathrm{~mm}$ (4.4-14), $p=0.001 /$ left $7.9 \mathrm{~mm}(2.6-12.9)$ vs $9.25 \mathrm{~mm}(5.7-16.8), p=0.04)$.

The right masseter muscle was thinner in patients with swallowing difficulty than without $[7.8 \mathrm{~mm}$ (min-max: 6.410.8) vs. $9.6 \mathrm{~mm}$ (min-max: 4.4-13.3) $\mathrm{p}=0.02$ ]. The left masseter muscle was thinner in patients with swallowing difficulty than without [7.8 mm (min-max: 5-10.5) vs. $9.2 \mathrm{~mm}$ (min-max: 5.216.8) $p=0.01]$. The right masseter muscle was also found to be thinner in patients with malnutrition than without $[7.8 \mathrm{~mm}$ (min-max: 5.4-9.9) vs 9 mm (min-max: 4.4-13.3) $(p=0.04)$ ].

Bilateral masseter muscles thicknesses were positively correlated with mini-nutritional assessment short-form scores (right $r: 0.466, p<0.01 /$ left $r: 0.385 p=0.01$ ) and negatively correlated with EAT-10 scores (right $r$ : $-0.366, p<0.01 /$ left $r$ : $-0.436 p<0.01)$.There was a positive correlation between masseter muscle thickness and HGS $(r=0.344, r=0.315, p<0.05)$ (Table 4).

Table 2: Assessment of jaw bite force and masseter muscle thicknesses in older and younger patients

\begin{tabular}{llll} 
& $\begin{array}{l}\text { Older patients } \\
\mathbf{n = 4 7}\end{array}$ & $\begin{array}{l}\text { Younger patients } \\
\mathbf{n = 1 1}\end{array}$ & $\mathbf{p}$ \\
\hline Right masseter thickness $(\mathrm{mm})$ & $8.4(3.3-13.3)$ & $11.3(6.4-14)$ & $<0.001$ \\
\hline Left masseter thickness $(\mathrm{mm})$ & $7.9(2.6-13.4)$ & $11.3(7.5-16.8)$ & $<0.001$ \\
\hline Jaw bite force, right $(\mathrm{N})$ & $38(13-106)$ & $180(60-270)$ & $<0.001$ \\
\hline Jaw bite force, left $(\mathrm{N})$ & $32.5(11-120)$ & $177(110-265)$ & $<0.001$ \\
\hline $\begin{array}{l}\text { Results were shown as median (min-max) for non-parametric, as mean } \pm \text { SD for parametric variables. } \\
\text { min-max: Minimum-maximum, SD: Standard deviation }\end{array}$ & & \\
\hline
\end{tabular}

Table 3: Correlation analysis of jaw bite force with other parameters

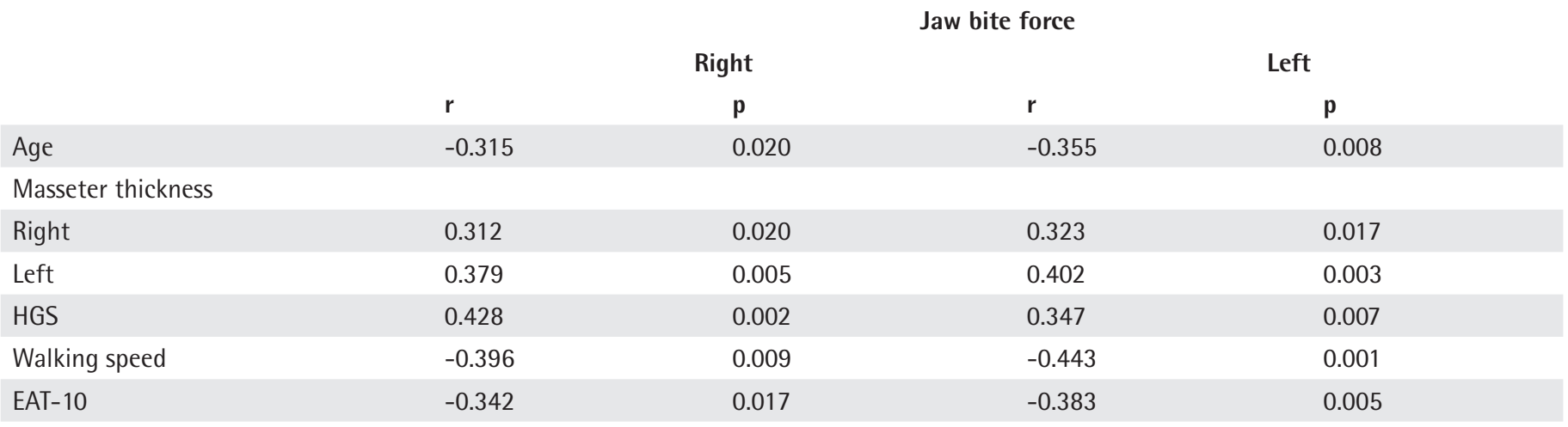

HGS: Handgrip strength, EAT-10: Eating assessment tool

Table 4: Correlation analysis of masseter thicknesses with other parameters

\begin{tabular}{llcl} 
& & Masseter thickness (r) & p \\
& Right & Left & $<0.05$ \\
\hline Age & -0.284 & -0.392 & $<0.05$ \\
\hline Jaw bite force & & & \\
\hline Right & 0.312 & 0.379 & $<.402$ \\
\hline Left & 0.323 & 0.385 & $<0.05$ \\
\hline MNA-SF & 0.466 & 0.315 & $<0.05$ \\
\hline HGS & 0.344 & -0.308 & $<0.05$ \\
\hline Walking speed & -0.256 & -0.436 & $<0.05$ \\
\hline EAT-10 & -0.366 & & \\
\hline MNA-SF: Mini nutritionel assessment-short form, HGS: Handgrip strength, EAT-10: Eating assessment tool & \\
\hline
\end{tabular}




\section{Discussion}

To our knowledge, this is the first study investigating the relationship between jaw bite force, masseter muscle and swallowing difficulty in older adults. We have shown that, bite strength and masseter muscle thickness scores were worse in older patients, those with prosthesis, in women, in those with malnutrition and negatively correlated with EAT-10 scores.

Previously, Yamaguchi et al. (15), confirmed that in healthy older adults, tooth loss has a stronger relationship with masseter muscle thickness and masseter muscle thickness is also associated with grip strength, in both men and women. Similar to the literature we have found a positive correlation between masseter muscle thickness and HGS, and masseter muscle thickness was thinner in patients with prosthesis.

Machida et al. (7) pointed out that, aging decreased tongue pressure more than jaw-opening force, and affected men more than women and sarcopenia affected tongue pressure and jaw-opening force, with the exception of jaw-opening force in women. The authors mentioned, tongue pressure and jawopening force are useful to predict the decline of swallowing function, and provide appropriate interventions preventing dysphagia (7). Wakasugi et al. (8) find out, among men, tongue pressure was correlated with grip strength and walking speed, whereas jaw opening force was correlated with grip strength. Among men, swallowing-related muscle strength was correlated with whole-body strength, and grip strength could thus serve as a simple indicator for swallowing-related muscle strength (8). The jaw bite measurement device was described to determine dental implant size, number of implants, and prosthetic design for restoring partial edentulism. The device seems to be costeffective that uses an off-the-shelf force transducer to measure patient bite force as a diagnostic aid (16). This is the first study investigating the relationship between jaw bite force and masseter muscle thickness and swallowing difficulty. We found that jaw bite force scores were lower in the older adults than young patients and in the patients with tooth prosthesis than without prosthesis. Additionally, jaw bite force was positively correlated with masseter muscle thicknesses and HGS and negatively correlated with EAT-10 scores. Thus measurement of jaw bite score-the easy and cost effective method- could predict HGS and become a part of sarcopenia assessment and obtain patients who will benefit from dysphagia management by predicting the swallowing difficulty.

Masseter muscle, which is easily accessable, assists the pharyngeal phase muscles that are mainly active in hyolaryngeal elevation; and, its activity starts at the beginning of the oral phase and continues until the end of swallowing (17). Despite the fact that masseter muscle is considered as a chewing muscle that is affected in the oral phase, it also has an important action during swallowing. In other words, it has an activity during both the oral and pharyngeal phases. Moreover, without the activity of the masseter muscle, insufficient supra- and infrahyoid muscles activity and prolonged swallowing time have been reported in trials evaluating the activity of the swallowing muscles (18). In a previous study, electrical stimulation bilateral masseter muscles may provide an effective treatment for both dysphagia and cognitive function in early stroke patients (19). We evaluated swallowing difficulty with EAT-10 test and found that bilateral masseter muscles thicknesses were negatively correlated with EAT-10 scores, similarly.

Gaszynska et al. (20) evaluated nutritional status with BMI and body cell mass index (BCMI) and pointed out that masseter muscle thickness was positively associated BCMI, BMI. We have found that the right masseter muscle was also found to be thinner in patients with malnutrition than without.

This study has some limitations. First, the sample size was small, therefore, the power of the study was low. Second, since this study was cross-sectional in design, we couldn't have information about the change in strength. Additionally, since we didn't have any data on muscle mass it was not possible to investigate the relation between local and systemic sarcopenia.

\section{Conclusion}

Decreasing of the jaw bite force and masseter muscle thickness with age, may be the reporter of malnutrition and swallowing difficulty. These parameters were positively correlated with muscle strength that they might be used in the sarcopenia diagnosis, especially in patients with tooth prothesis. Further studies with larger number of patients are needed to determine if these parameters predict swallowing dysfunction and sarcopenia in older adults.

\section{Ethics}

Ethics Committee Approval: The study was approved by the Ethics Committee of Gazi University, Faculty of Medicine, 01/2016-110.

Informed Consent: Informed consent was obtained from all patients.

Peer-reviewed: Externally peer-reviewed.

\section{Authorship Contributions}

Surgical and Medical Practices: G.Ş.A., G.A., B.C., I.Y., M.D., Concept: G.S..A., Z.Ü., Design: G.S..A., Z.Ü., Data Collection or Processing: G.Ş.A., G.A., B.C., Analysis or Interpretation: G.Ş.A., M.C.K., Literature Search: G.Ş.A., G.A., B.C., Writing: G.Ş.A., Z.Ü.

Conflict of Interest: No conflict of interest was declared by the authors. 
Financial Disclosure: The authors declared that this study received no financial support.

\section{References}

1. Müller F, Hernandez M, Grütter L, et al. Masseter muscle thickness, chewing efficiency and bite force in edentulous patients with fixed and removable implant-supported prostheses: a cross-sectional multicenter study. Clin Oral Implants Res. 2012;23:144-150.

2. Kikutani T, Yoshida M, Enoki H, et al. Relationship between nutrition status and dental occlusion in community-dwelling frail elderly people. Geriatr Gerontol Int. 2013;13:50-54.

3. Bhoyar PS, Godbole SR, Thombare RU, et al. Effect of complete edentulism on masseter muscle thickness and changes after complete denture rehabilitation: an ultrasonographic study. J Investig Clin Dent. 2012;3:4550.

4. Newton JP, Yemm R, Abel RW, et al. Changes in human jaw muscles with age and dental state. Gerodontology. 1993;10:16-22.

5. Sahyoun NR, Lin CL, Krall E. Nutritional status of the older adult is associated with dentition status. J Am Diet Assoc. 2003;103:61-66.

6. Cruz-Jentoft AJ, Bahat G, Bauer J, et al. Sarcopenia: revised European consensus on definition and diagnosis. Age Ageing. 2019;48:16-31.

7. Machida $N$, Tohara $H_{1}$ Hara $K$, et al. Effects of aging and sarcopenia on tongue pressure and jaw-opening force. Geriatr Gerontol Int. 2017;17:295301.

8. Wakasugi $Y$, Tohara $H$, Machida $N$, et al. Can grip strength and/or walking speed be simple indicators of the deterioration in tongue pressure and jaw opening force in older individuals? Gerodontology. 2017;34:455-459.

9. Vellas B, Guigoz Y, Garry PJ, et al. The Mini Nutritional Assessment (MNA) and its use in grading the nutritional state of elderly patients. Nutrition. 1999;15:116-122.
10. Katz $\mathrm{S}$, Ford AB, Moskowitz RW, Jackson BA, Jaffe MW. Studies of illness in the aged. The index of ADL: A standardized measure of biological and psychosocial function. JAMA. 1963;185:914-91.

11. Arik G, Varan HD, Yavuz BB, et al. Validation of Katz index of independence in activities of daily living in Turkish older adults. Arch Gerontol Geriatr. 2015;61:344-350

12. Lawton MP, Brody EM. Assessment of older people: self-maintaining and instrumental activities of daily living. Gerontologist. 1969;9:179-186.

13. Folstein MF, Folstein SE, McHugh PR. "Mini-mental state". A practical method for grading the cognitive state of patients for the clinician. Psychiatr Res. 1975;12:189-198.

14. Yesavage JA, Brink TL, Rose $T L$, et al. Development and validation of a geriatric depression screening scale: a preliminary report. J Psychiatr Res. 1982-1983;17:37-49.

15. Yamaguchi $\mathrm{K}$, Tohara $H_{\text {, Hara }} \mathrm{K}$, et al. Relationship of aging, skeletal muscle mass, and tooth loss with masseter muscle thickness. BMC Geriatr. 2018;18:67.

16. Flanagan $\mathrm{D}$, llies $\mathrm{H}, \mathrm{O}^{\prime} B$ rien $\mathrm{B}$, et al. Jaw bite force measurement device. J Oral Implantol. 2012;38:361-364.

17. Pernambuco Lde A, Silva HJ, Lima LM, et al. Electrical activity of masseter muscle in young adults during swallowing of liquid. J Soc Bras Fonoaudiol. 2011;23:214-219.

18. Hiraoka K. Effect of teeth clenching on swallowing motor patterns in humans. Int J Neurosci. 2006;116:1005-1012.

19. Umay EK, Yaylaci A, Saylam G, et al. The effect of sensory level electrical stimulation of the masseter muscle in early stroke patients with dysphagia: A randomized controlled study. Neurol India. 2017;65:734-742.

20. Gaszynska E, Godala M, Szatko F, et al. Masseter muscle tension, chewing ability, and selected parameters of physical fitness in elderly care home residents in Lodz, Poland. Clin Interv Aging. 2014;9:1197-1203. 